\title{
POLÍTICA, BUROCRACIA E REDES SOCIAIS: AS NOMEAÇÕES PARAO ALTO ESCALÃO DO BANCO CENTRAL DO BRASIL ${ }^{1}$
}

\author{
Cecília Olivieri
}

\begin{abstract}
RESUMO
O estudo das nomeações para os cargos de direção do Banco Central do Brasil, pela análise de redes sociais, permite compreender aspectos fundamentais do sistema politico-administrativo brasileiro. A escolha dos dirigentes públicos afeta a governabilidade e a governança do país. A troca entre cargos e o apoio parlamentar podem garantir a estabilidade do governo, mas também podem reduzir o controle do Presidente da República sobre a burocracia e sobre a direção das políticas públicas. A análise de redes sociais permite a construção dos critérios de escolha dos dirigentes públicos, revela novos padrões de interface entre Estado e sociedade e ilumina o estudo da accountability entre dirigentes públicos e a burocracia e entre governo e sociedade.
\end{abstract}

PALAVRAS-CHAVE: nomeação; burocracia; redes sociais; Banco Central; accountability.

\section{INTRODUÇÃO}

Existem 67.997 cargos ou funções de confiança na estrutura do Poder Executivo federal brasileiro. São cargos em comissão, de livre provimento ou de livre nomeação, cujos ocupantes são escolhidos pelo Presidente da República. Entre estes, há 19.202 cargos de Direção e Assessoria Superior (DAS), que abrangem desde os altos cargos de direção e assessoria até cargos médios de gerência. Cerca de 19\% dos DAS são responsáveis pela alta direção ministerial e assessoria do governo (por exemplo, assessores da Presidência da República, secretários ministeriais e dirigentes de órgãos da administração indireta). Os DAS restantes (81\%) ocupam os níveis médios de gerência e assessoria. Além destes, há 53 cargos de natureza especial, que também compõem $\mathrm{o}$ alto escalão (como os ministros de Estado e diretores do Banco Central) e 48.742 cargos e funções de confiança e gratificações; para estes últimos, não há dados disponíveis que possibilitem verificar em qual nível hierárquico estão (BRASIL, 2005).

\footnotetext{
1 Este artigo é fruto do desenvolvimento de reflexões apresentadas na dissertação de mestrado da autora (OLIVIERI, 2002).
}

A escolha para os cargos de livre nomeação não é importante apenas por causa da expressiva quantidade de cargos ou da posição relevante que parte significativa deles ocupa na estrutura do governo. Ela é importante, principalmente, porque afeta diretamente a governabilidade e a governança do sistema político-administrativo brasileiro. A capacidade de o governo manter uma base parlamentar estável e aprovar seus projetos depende, entre outros tipos de "moeda" política, da troca de cargos da estrutura governamental por apoio de parlamentares e de partidos. Porém, essa troca afeta a governança, isto é, a capacidade de o governo formular e implementar políticas públicas, pois estas dependem, em boa parte, da escolha de pessoas capazes de realizar os projetos do governo e que estejam politicamente afinadas com seus objetivos. Este é um mecanismo básico de funcionamento do nosso sistema político, que decorre do nosso presidencialismo de coalizão, ou seja, da necessidade de formar um governo baseado em uma coalizão de partidos, em função do sistema multipartidário brasileiro (ABRANCHES, 1988).

O papel da escolha para os cargos de confiança no sistema presidencialista brasileiro é como o de uma faca de dois gumes, que pode garantir ao Presidente da República o controle sobre a atuação da burocracia, caso os escolhidos ajam de 
acordo com as diretrizes do governo, mas que também pode impedir esse controle, no caso de os nomeados estarem comprometidos com outros interesses ou projetos. A nomeação para os cargos de direção é um dos principais instrumentos de controle do Presidente da República sobre a burocracia (WOOD \& WATERMAN, 1991). Sem esse controle, o Presidente não tem como implementar seu projeto de governo, e suas chances de cumprir um mandato bem-sucedido reduzem-se.

O grau em que políticos eleitos podem influenciar decisões de burocratas e vice-versa é definido, em boa parte, pelo processo de nomeação e é um componente decisivo da relação entre política e burocracia. No caso brasileiro, em que os cargos de livre provimento são contados em dezenas de milhares, o estudo das nomeações é uma forma privilegiada de compreender a relação entre política e burocracia. A escolha para os cargos de confiança é o momento em que o Presidente da República concilia as exigências de governança e de governabilidade. Essa dupla exigência é uma das expressões da idéia weberiana de complementaridade entre política e burocracia, segundo a qual os papéis de políticos e de burocratas são indissociáveis e complementares, apesar da separação e diferenciação entre suas atribuições e responsabilidades e do potencial conflito entre suas posições (COHN, 1993).

A possibilidade de o Presidente escolher seus assessores diretos e os altos dirigentes públicos é inerente à democracia; não seria desejável burocratizar o alto escalão do governo, impedindo sua substituição conforme a alternância de poder decorrente das eleições, porque isso impediria a responsabilização política do governo (WEBER, 1993). Esta situação é o oposto do que o modelo weberiano de burocracia prescreve para os escalões médios e baixos, nos quais devem vigorar mecanismos de redução da influência da luta política na administração cotidiana do governo, como a escolha dos funcionários por mérito e a ascensão por meio da progressão na carreira.

No caso brasileiro, a influência dos políticos na burocracia atinge profundamente a estrutura burocrática. Isso indica uma forte influência dos políticos eleitos sobre as decisões da burocracia, pois eles ocupam ou podem indicar quem vai ocupar cargos de direção em níveis médios da estrutura do governo. A maior parte dos estudos sobre burocracia no Brasil concentrou-se nessa distorção da estrutura burocrática nacional e analisou a relação entre política e burocracia sob um viés negativo, como veremos na terceira seção. $\mathrm{O}$ alto escalão governamental, em que a livre nomeação é e deve ser a regra, foi pouco estudado, e não pode sê-lo com base nos mesmos conceitos e avaliações das relações entre política e burocracia que vigoram na literatura.

A próxima seção discute as peculiaridades do Banco Central (BC) como objeto de estudo, os motivos de sua escolha e a metodologia adotada no trabalho. Por intermédio do estudo das nomeações para os cargos de Presidente e Diretor do Banco Central do Brasil, foram identificados os critérios de nomeação e suas conseqüências para a formulação e implementação de políticas públicas. $\mathrm{O}$ trabalho analisou as nomeações realizadas entre 1985 e 2000 , período em que houve 13 presidentes e 55 diretores ${ }^{2}$.

A terceira parte retoma brevemente a literatura que tem tratado da relação entre política e burocracia no Brasil. Estudos fundamentais sobre a formação do Estado e da burocracia nacionais construíram uma oposição analítica entre política e administração que concebe a influência da política na burocracia apenas como fonte de irracionalidade e ineficiência. Trabalhos mais recentes, que concentraram atenção nas relações pessoais subjacentes às estruturas formais da organização governamental, permitem uma melhor compreensão do imbricamento dos conteúdos políticos e técnicos da atuação dos dirigentes governamentais.

A quarta seção delineia o perfil altamente técnico e especializado dos profissionais escolhidos para a direção do Banco Central. Esse critério é importante para a nomeação porque o exercício da autoridade monetária exige especialização e competência técnica. Entretanto, critério fundamental para a escolha desses dirigentes é a habilidade de conciliar conhecimento técnico e obje-

2 As principais fontes de informações foram os currículos dos nomeados e entrevistas. Foi possível ter acesso aos currículos de todos os presidentes e de 52 diretores, constituindo um universo de análise de 65 nomeados. Foram entrevistados, entre agosto e outubro de 2001, sete ex-presidentes, cinco ex-diretores, um ex-Ministro da economia, um Senador da República e uma jornalista especializada na cobertura do Banco Central. 
tivos políticos. Essa habilidade é construída na rede social, pela circulação dos profissionais por várias instituições públicas e privadas.

A quinta parte desenvolve a idéia de pertencimento à rede social como forma de construção do reconhecimento profissional e das relações de confiança. Os atributos pessoais e profissionais dos nomeados, fundamentais para definir sua nomeação, são avaliados por meio da rede social, ou seja, pela experiência profissional conjunta, do compartilhamento de identidades intelectuais e das relações pessoais de confiança. O que caracteriza os nomeados não é a competência profissional ou a formação de alto nível, mas, sim, o pertencimento a uma rede social de relações pessoais e profissionais.

A última seção retoma as principais conclusões do artigo sob o ponto de vista das relações entre Estado e sociedade e da accountability governamental.

\section{AUTORIDADE MONETÁRIA E REDE SO- CIAL}

Apesar de a Constituição Federal de 1988 atribuir ao Presidente da República o poder de nomear os dirigentes do Banco Central (artigo 84, inciso XIV), esse poder é, de fato, delegado ao Ministro da Fazenda, que exerce um papel decisivo na escolha do Presidente do Banco. A escolha dos diretores, por sua vez, fica a cargo do Presidente do Banco Central, com possibilidades de influência do Ministro da Fazenda e da equipe econômica que variam a cada governo. Como o Presidente da República delega a escolha desses dirigentes ao Ministro e ao Presidente do Banco Central, foi possível analisar o processo de escolha dos nomeados basicamente a partir de entrevistas com os ex-presidentes do Banco.

A principal conclusão do trabalho é que as nomeações para diretores do Banco Central são eminentemente técnicas, mas o critério pessoal de escolha dos nomeados é fundamental. O Banco Central se caracteriza como uma instituição insulada e meritocrática, e por isso o critério técnico é primordial na escolha de seus dirigentes. Entretanto, a nomeação depende, essencialmente, de relações pessoais que se estabelecem com base em vínculos profissionais e em identidades intelectuais, ideológicas e pessoais. Essas relações estruturam-se em uma rede social, que é formada por intermédio da circulação por cargos em instituições públicas, privadas e acadêmicas. A alta circulação entre as instituições dá origem a um profissional híbrido, com experiências e competências profissionais mistas, impedindo uma diferenciação estrita entre carreiras profissionais privadas e públicas. A experiência em várias instituições e a conciliação de competências técnicas e políticas são as principais contribuições desse profissional híbrido para instituições governamentais que, como o Banco Central, atuam tanto na formulação e implementação de políticas públicas quanto na regulação do mercado.

A escolha do Banco Central como objeto de análise permitiu o estudo de uma burocracia reconhecida pela sua competência técnica e, ao mesmo tempo, muito próxima do núcleo político do governo. O Banco Central é considerado uma das ilhas de excelência técnica do governo federal, ao lado de instituições como o Instituto de Pesquisa Econômica Aplicada (Ipea) e o Banco Nacional de Desenvolvimento Econômico e Social (Bndes), pois são organizações burocráticas com carreiras estruturadas e relativamente bem remuneradas, portanto, com concursos públicos bastante concorridos, que atraem profissionais com boa formação e que têm estímulos durante a carreira para aperfeiçoar-se profissionalmente (LOUREIRO \& ABRUCIO, 1999).

O Banco Central está inserido no núcleo decisório do poder Executivo, uma vez que seu Presidente faz parte do gabinete presidencial. O estudo do caso de uma instituição que ocupa lugar de destaque no processo de decisão política, cuja atividade é fortemente permeada por conteúdo técnico e que requer de seu corpo funcional comprovada expertise profissional, configura um desafio a uma análise da nomeação de técni$\cos$ e burocratas que não recorra aos conceitos de clientelismo nem de insulamento burocrático. Esses conceitos, como veremos adiante, são os mais recorrentes na literatura que estuda esse tipo de instituição, mas não são suficientes para captar a complexidade das relações entre política e burocracia e entre Estado e sociedade no Brasil moderno.

O Banco Central é responsável pela política macroeconômica e pela fiscalização bancária. A implementação dessas políticas não depende apenas da autoridade estabelecida, ou seja, do poder derivado da autoridade formal, que expressa-se por normas e regulamentos formais. Ela depende 
também, e fundamentalmente, conforme a análise de Weber sobre as diferentes fontes de poder das instituições, do poder derivado da "constelação de interesses que se desenvolve em um mercado livre" (SOLA, 1995, p. 49). A autoridade formal é aquela que impõe-se pela formulação e aplicação das normas, e nesse aspecto o Banco Central é semelhantes às demais instituições públicas que impõem o cumprimento de normas por meio da aplicação de punições aos recalcitrantes. $O$ poder derivado da constelação de interesses, por outro lado, refere-se ao poder de induzir comportamentos, como a atuação do Banco Central nas operações de mercado aberto.

A relação com essa constelação de interesses e a sua correta avaliação é habilidade fundamental da autoridade monetária e coloca sobre seus dirigentes a tarefa do delicado equilíbrio entre os interesses privados e o interesse público. Esses interesses são diferentes e expressam visões potencialmente conflitantes sobre o funcionamento do mercado financeiro, mas precisam ser compatibilizados pela autoridade monetária.

O interesse do mercado financeiro consiste, basicamente, em assumir riscos para obter retorno. Sua tendência é, portanto, assumir mais riscos para realizar retornos maiores. Sua função social é exatamente essa: assumir riscos financeiros de forma mais eficiente do que as instituições não financeiras. Todavia, o Banco Central tem por função primordial limitar os riscos, de acordo com uma regra de prudência, impedindo que sua assunção imprudente pelo mercado leve a uma crise generalizada da economia. Ou seja, o Banco Central deve garantir a segurança do funcionamento do mercado sem extinguir o risco financeiro. Essas visões são opostas e potencialmente conflitantes porque, para o mercado, o interesse por ganhos maiores leva à assunção crescente de riscos, enquanto, para o Banco Central, a situação ideal, no limite, é a ausência de risco. O Banco Central, no entanto, não pode suprimir totalmente o risco, pois isto significaria o desaparecimento da própria razão de existência do mercado financeiro, pela perda de seu incentivo econômico. O Banco Central deve, então, equilibrar as duas posições, tendo em vista os interesses privados e o bom funcionamento do sistema econômico.

Decisões de caráter técnico, como as decisões do Banco Central sobre política monetária e cambial, têm, inevitavelmente, um conteúdo político, no sentido de que afetam a atuação e os interesses de grupos econômicos, enfim, alteram a distribuição de recursos na sociedade. Nesse sentido, o Banco Central é uma das mais importantes instâncias de governo quanto à capacidade de promover realocação de recursos econômicos e, por isso, a indicação de seus dirigentes tornase objeto de disputa de grupos empresariais e políticos.

Apesar de não poder-se negar essa disputa pelas posições de direção do Banco Central, é muito difícil demonstrar concretamente a existência de conexões entre os nomeados e esses postos e redes políticas, em especial a partir das fontes de dados selecionadas para este trabalho entrevistas e currículos -, pois os nomeados geralmente não têm atuação político-partidária nem explicitam ou assumem publicamente suas relações com grupos políticos ou corporativos.

O que é possível afirmar, no caso brasileiro recente, é que, se esses cargos não fossem tão cobiçados, em função de seu enorme poder, não seria necessário que o Presidente da República adotasse estratégias para "blindar" o Banco Central (para usar a expressão dos jornais diários e seus analistas políticos), ou seja, para insulá-lo de outras influências e disputas políticas, sejam partidárias, sejam corporativistas. Essa "blindagem" ou insulamento expressa-se no fato de que os cargos de direção do Banco Central, ao contrário dos de outras instituições governamentais, têm ficado na "cota do Presidente", ou seja, não entram nas negociações de cargos por apoio político dos partidos do Congresso. Nos últimos três governos, os cargos de direção econômica, por exemplo, os principais postos do Ministério da Fazenda e do Banco Central, têm sido escolhidos diretamente pelo Presidente, sem interferência de negociações partidárias. A rigor, as negociações partidárias constituem a base de sustentação desta autonomia do Presidente para nomear os principais postos de direção econômica, uma vez que a distribuição de outros cargos, fora da área econômica, é que garante ao Presidente essa autonomia (LOUREIRO \& ABRUCIO, 1999). Esta busca por autonomia, por intermédio de negociações políticas, significa a tentativa de o Presidente da República garantir que seu grupo político e suas idéias predominem na direção do Banco Central, em oposição a outros grupos com 
idéias ou interesses divergentes que tentem influenciar suas decisões.

A análise de redes sociais foi adotada porque permite compreender os aspectos não institucionais (como as relações pessoais de confiança e as trajetórias de carreira) envolvidos na escolha para os cargos de confiança. No Brasil, a importância destes aspectos no momento da nomeação é muito grande. Além de as relações pessoais serem importantes para o funcionamento do governo - como veremos nas análises de Schneider (1994) e de Loureiro e Abrucio (1999), na próxima seção -, o processo de nomeação é caracterizado por uma grande margem de discricionariedade do nomeador, pois não há mecanismos institucionais que restrinjam a sua escolha. No Brasil, não há critérios definidos, $a$ priori, que limitem a escolha do Presidente da República para os cargos de confiança.

Esta situação é oposta à dos Estados Unidos, por exemplo, em que existe um processo de avaliação prévia dos nomes indicados pelo Presidente da República. Neste processo, conhecido como clearence, os nomes dos indicados pelo Presidente passam rotineira e sistematicamente por um escrutínio formal quanto à sua vida profissional pregressa e quanto a possíveis conflitos de interesse entre a atividade profissional do indicado e as funções públicas que assumirá (MACKENZIE \& SHOGAN, 1996). A avaliação inclui a consulta informal às comissões do Congresso encarregadas de aprovar as nomeações, com intensa negociação política entre os poderes Executivo e Legislativo quanto aos nomes indicados, como forma de evitar a apresentação de nomes politicamente inviáveis e uma votação contrária ao governo.

No Brasil, não existe nada parecido com esse processo formal e semi-impessoal de seleção de indicados para os cargos de confiança. A seleção é realizada com base em relações pessoais e de confiança, e a avaliação prévia dos nomes depende de informações disponíveis na rede social de relações profissionais e pessoais.

Rede social é o conjunto das relações estabelecidas com base em vínculos de afinidade pessoal, identidade intelectual e convivência profissional. Esses vínculos são distintos mas não são excludentes, ou seja, relações de amizade podem sobrepor-se às relações baseadas na convivência profissional ou na colaboração acadêmi- ca. Como veremos adiante, estes vínculos tendem a sobrepor-se, refletindo a grande circulação dos profissionais entre várias instituições e a decorrente criação de vários tipos de relacionamento.

Além de permitir a compreensão dos aspectos não institucionais envolvidos na escolha dos indicados, a análise de redes é um instrumento potente para a análise da relação entre espaços públicos e privados, porque "permite identificar detalhadamente os padrões de relacionamento entre atores de uma determinada situação social, assim como suas mudanças no tempo" (MARQUES, 1999, p. 49). As conexões entre espaço público e privado são importantes no caso do Banco Central, porque mais da metade dos profissionais que ocuparam cargos de direção no período analisado eram profissionais com atuação em instituições reguladas pelo Banco, como instituições bancárias e financeiras.

A rede permite compreender as relações internas aos diversos grupos aos quais estes profissionais pertencem, como os burocratas e os profissionais do mercado, mas também permite compreender a relação dinâmica entre profissionais que atuam nas instituições privadas e os profissionais que exercem a autoridade pública. Essas relações são determinadas pelos interesses dos atores (progredir na carreira e/ou influenciar a direção da política econômica) e pelas formas de acesso aos recursos de poder (ser nomeado e influenciar nomeações) e não pelas estruturas formais das instituições, sejam públicas, sejam privadas.

A análise de redes interpessoais de Mark Granovetter é o referencial deste trabalho. A preocupação de Granovetter (1973) é explicar os mecanismos de interação social, dentro da perspectiva sociológica que analisa a estrutura social. Este trabalho, por sua vez, está preocupado com as relações políticas e quer compreender o processo de nomeação. Apesar da diferença quanto a objetivos e problemas teóricos entre este trabalho e o de Granovetter, a análise de redes é instrumento útil para o estudo das nomeações porque permite uma análise das relações interpessoais entre os atores sem que seja preciso partir de uma definição a priori e restritiva de seus interesses. Adotar a análise de rede social da sociologia não significa realizar um estudo estruturalista da política, mas apenas buscar entender um fenômeno 
para o qual a análise institucional da Ciência Política não tem instrumentos ou cujos instrumentos não alcançam o que queremos entender (a teoria da agência, que trata da relação de delegação, não permite entender o caráter político da relação pessoal e de confiança que está além da relação hierárquica).

Para Granovetter (1973), as relações interpessoais podem ser fortes ou fracas. As relações fortes são ligações entre pessoas com afinidades e semelhanças, que tendem a formar grupos homogêneos e fechados. Os laços fracos ligam pessoas com menos afinidades e têm o potencial de colocar esses grupos homogêneos em contato, ampliando a possibilidade de difusão de conhecimento, de mobilidade e de coesão social. Sua tese é de que uma sociedade organizada preponderantemente com base em laços sociais fortes tende, paradoxalmente, à desagregação, devido ao isolamento dos grupos em si mesmos. Observa também que são os laços fracos os responsáveis pela comunicação e pelas trocas na sociedade e, conseqüentemente, são imprescindíveis à manutenção da coesão social. O pesquisador mede a força do laço interpessoal como uma combinação de quantidade de tempo que as pessoas passam juntas, de intensidade emocional, de intimidade e confiança mútua e de serviços recíprocos prestados (GRANOVETTER, 1973). Ele demonstrou objetivamente a importância dos laços fracos por intermédio do estudo sobre a procura por emprego. Os laços fracos mostraram-se mais eficientes no acesso a informações sobre oportunidades de emprego, uma vez que o percentual de profissionais que encontrou um novo emprego por este meio é maior do que o percentual de profissionais que o conseguiram pelos laços fortes. A "força" ou o potencial dos laços fracos está em conectar o profissional com indivíduos de outros grupos que detêm informações sobre oportunidades profissionais diferentes das informações detidas pelo profissional e pelas pessoas com que mantém laços fortes (GRANOVETTER, 1983).

No caso do Banco Central, a aplicação do estudo de rede social tem por objetivo compreender as formas de inter-relação entre os profissionais, com base tanto em seus interesses individuais - interesse de carreira e interesse em influenciar políticas públicas - quanto em seus recursos pessoais, profissionais e institucionais. Os interesses variam conforme as mentes e os corações, e consideramos que não podem ser presumidos, mas apenas avaliados caso a caso. Os recursos pessoais, profissionais e institucionais variam de acordo com a instituição, que conforma a identidade do profissional - burocrata ou profissional do mercado - e suas oportunidades de carreira.

Esta seção termina com uma ressalva sobre os limites do trabalho. Não foram analisadas as trajetórias de carreira após a passagem pelo Banco Central nem houve a preocupação em avaliar os conflitos éticos potencialmente envolvidos na interface entre carreiras privadas e públicas. A análise da carreira dos nomeados não perseguiu sua trajetória posterior à passagem pelo Banco Central, pois o interesse do trabalho é o processo de nomeação. Portanto, não é possível fazer afirmações sobre o desenvolvimento da carreira dos profissionais após a passagem pelo Banco Central. Da mesma forma, questões como tráfico de influência ou uso de informações privilegiadas em benefício próprio não foram objeto deste estudo, apesar de sua conexão com o tema das relações entre interesses públicos e privados.

\section{POLÍTICA, BUROCRACIA E NOMEAÇÕES}

Este trabalho pretende, pelo estudo das nomeações, mostrar que é possível analisar a relação entre política e burocracia no Brasil sem recorrer à dicotomia entre clientelismo e insulamento burocrático, que é a principal matriz analítica dos estudos sobre a formação da burocracia na literatura nacional. Trabalhos clássicos como os de Maria do Carmo Campello de Souza (1976), Luciano Martins (1985), Bárbara Geddes (1990) e Edson Nunes (1999) trataram a relação entre política e burocracia predominantemente pela dicotomia entre clientelismo e insulamento burocrático (OLIVIERI, 2002).

Para esta literatura, existem duas burocracias: a patrimonialista e a insulada. A burocracia patrimonialista é influenciada pela política partidária e é, por este motivo, ineficiente. No extremo oposto está a burocracia insulada em relação ao Congresso, aos partidos políticos e à sociedade e que, devido a esse isolamento, caracterizase pelo comprometimento com a racionalidade técnica e com a eficiência administrativa. Essa dicotomia supõe uma separação estanque entre política e burocracia e impede a compreensão da influência legítima da política na burocracia, bem como do papel dos dirigentes públicos. 
Os trabalhos de Maria Rita Loureiro e Fernando Abrucio (1998) superam essa dicotomia ao mostrarem que a nomeação não é exclusivamente política ou técnica, mas, sim, uma conjunção dos dois fatores. Para compreender a relação entre política e burocracia no Brasil em outro paradigma que não o desta dicotomia empobrecedora, Loureiro e Abrucio (1998) adotaram a idéia de formulador de política ou, na expressão mais freqüentemente utilizada pela literatura, policymaker.

Análises recentes do desenvolvimento da relação entre políticos e burocratas apontam para a "mistura" crescente entre seus papéis e atribuições, criando o fenômeno da politização da burocracia e da burocratização da política. O modelo de separação estrita de funções e de capacidades entre políticos e burocratas (segundo o qual os políticos decidem e inovam, e os burocratas obedecem e garantem a continuidade das políticas) está sendo substituído, principalmente nos altos escalões, por um modelo híbrido, em que policymakers combinam as duas funções e habilidades, como mostrou o estudo comparativo de Aberbach, Putnam e Rockman (1981). Esse fenômeno deu origem a um profissional híbrido que é responsável tanto pela gestão eficiente quanto por atender aos objetivos políticos da agenda governamental. Os ocupantes do alto escalão do governo, sejam políticos, sejam burocratas, são policymakers que devem ser capazes de responder a essa dupla exigência.

Loureiro e Abrucio (1998) estudaram os critérios de nomeação dos ministros dos governos José Sarney, Fernando Collor, Itamar Franco e Fernando Henrique Cardoso (FHC), entre 1985 e 1998. Nesse período, os ministros foram escolhidos com base em seis critérios, definidos pelos pesquisadores: pessoal, técnico, partidário, federativo, de imagem e de grupos de interesse. O peso dos critérios nas nomeações variou conforme cada governo e conforme a área do ministério em questão. O importante a destacar é que os critérios não são excludentes, ou seja, cada nomeação pode representar a conciliação entre, por exemplo, critérios ou lógicas técnicas e federativas.

As principais conclusões de Loureiro e Abrucio (1998) são que não há nomeações puramente técnicas e que a lógica da política não esgota-se na escolha conforme critérios clientelistas. Diante da necessidade de obter apoio político, o Presidente da República nomeia alguém que atenda tanto ao critério político quanto ao critério de confiança pessoal. $\mathrm{O}$ indicado atende à necessidade do Presidente da República de apoio no Congresso, de apoio de algum partido ou de algum grupo da sociedade, mas permite que o Presidente controle a atuação do nomeado pelas relações pessoal e de confiança. Da mesma forma, ao escolher alguém com perfil preponderantemente técnico, o Presidente certifica-se da fidelidade política ou da identidade ideológica do escolhido ao projeto do governo por critérios pessoais ou de confiança.

Na sua análise sobre as instituições públicas que promoveram a política industrial no Brasil da década de 1970, Ben Schneider (1994) revela o papel determinante das relações pessoais de confiança na estruturação da elite governamental e na formulação e implementação de políticas públicas. Para o autor, o sucesso da política industrial brasileira foi resultado das articulações informais entre os profissionais envolvidos na formulação e implementação das políticas e não das relações formais e institucionais.

Uma das principais conclusões de Schneider é que, no Estado brasileiro, a estrutura de poder que importa é a definida pelas nomeações e pelas trajetórias de carreiras dos profissionais. A estrutura formal da organização burocrática brasileira é fragmentada e desarticulada, impedindo a estruturação de políticas públicas nos moldes tradicionais. A alta circulação dos funcionários entre vários órgãos e a dependência das relações pessoais para a progressão na carreira, por um lado, agravam a fraqueza das organizações, mas, por outro, foram responsáveis pela capacidade de coordenação e de formulação das políticas. As desvantagens de um ambiente organizacional fragmentado e da fraca lealdade organizacional foram supridas, com sucesso, pelas relações informais baseadas em vínculos pessoais e profissionais.

O peso que as relações pessoais e de confiança exercem na nomeação e nas carreiras dos altos escalões do governo no Brasil é muito grande, mas não pode ser confundido com o clientelismo. Da mesma forma, em algumas instituições, como o Banco Central, o peso do critério técnico é importante, mas não basta para caracterizar seu insulamento. A nomeação baseada 
em critérios pessoais não é apenas uma forma de agraciar amigos ou recompensar correligionários, nem a nomeação com base em critérios técnicos significa a eliminação da influência da política na burocracia; ambos são instrumentos que permitem aos políticos transmitir à burocracia as prioridades e a agenda do governo.

Vejamos, agora, quem são os policymakers do Banco Central e como suas características influenciam a formulação e implementação das políticas públicas.

\section{PERFIS DE CARREIRA, PROFISSIONAL HÍBRIDO E POLICYMAKING}

A competência técnica é indispensável para a indicação à diretoria do Banco Central, mas o que define a nomeação não é uma avaliação sobre atributos profissionais. O que diferencia os profissionais nomeados não é seu nível de qualificação técnica. A principal distinção refere-se ao grau de inserção na rede e de hibridismo de suas carreiras. Dentro do universo de prováveis indicados, os profissionais com carreira mais híbrida e com mais inserção na rede são os nomeados, e, entre os nomeados, são os profissionais mais híbridos e mais inseridos que ocupam os cargos de policymaker, ou seja, a Presidência e as diretorias ligadas à formulação da política macroeconômica.

Os policymakers são, originalmente, burocratas e profissionais de fora. As diferenças entre eles referem-se à sua formação, ao grau de hibridismo de suas carreiras e ao tipo de cargo que ocupam no Banco Central. As diretorias ligadas à elaboração da política macroeconômica e a Presidência são ocupadas predominantemente por profissionais de fora. As áreas de formação acadêmica são praticamente as mesmas para ambos os profissionais, mas os burocratas são treinados para as atividades específicas do Banco Central e realizam, proporcionalmente, menos cursos de pós-graduação do que os profissionais de fora. Por fim, as carreiras dos burocratas são menos híbridas.

Entre os diretores, há uma proporção semelhante de profissionais de fora e de burocratas. Já entre os presidentes, existe uma grande desproporção, predominando os profissionais de fora, conforme a tabela a seguir.
TABELA 1 - RELAÇÃO ENTRE PROFISSIONAIS DE FORAE BUROCRATAS

\begin{tabular}{|l|c|c|}
\hline CARGOS & $\begin{array}{c}\text { PROFISSIONAIS } \\
\text { DE FORA }\end{array}$ & BUROCRATAS \\
\hline Diretores & $56 \%$ & $44 \%$ \\
Presidentes & $70 \%$ & $30 \%$ \\
\hline
\end{tabular}

FONTE: a autora.

Apesar de a proporção de diretores de dentro e de fora ser muito semelhante, eles não distribuem-se igualmente entre as diretorias. As diretorias ligadas à elaboração da política macroeconômica, como as de política monetária e cambial, tendem a ser ocupadas pelos profissionais de fora. Os burocratas, por sua vez, predominam nas diretorias envolvidas com atividades de fisscalização e normatização bancária e nas diretorias relacionadas a assuntos internos do Banco Central, como a administrativa, por exemplo.

\section{TABELA 2 - COMPOSIÇÃO DAS DIRETORIAS}

\begin{tabular}{|l|c|c|}
\hline CARGOS & $\begin{array}{c}\text { PROFISSIONAIS } \\
\text { DE FORA }\end{array}$ & $\begin{array}{c}\text { BURO- } \\
\text { CRATAS }\end{array}$ \\
\hline $\begin{array}{l}\text { Diretorias de polí- } \\
\text { ticas monetária e } \\
\text { cambial }\end{array}$ & 25 & 7 \\
$\begin{array}{l}\text { Diretorias de fis- } \\
\text { calização, norma- } \\
\text { tização e adminis- } \\
\text { tração** }\end{array}$ & 6 & 18 \\
\hline
\end{tabular}

\section{FONTE: a autora.}

NOTAS:

1. Não foram computados os ocupantes de diretorias estranhas às atividades de central banking, e não classificáveis nos termos desta comparação, como as Diretorias de Crédito Rural e Industrial (Dicri), da Dívida Pública (Didip), da Dívida Externa (Divex), que foram extintas em 1989, nem a Diretoria de Finanças Públicas e Regimes Especiais (Difip), que foi criada em 1996.

2. * Inclui as diretorias Bancária (Diban), de Mercado de Capitais (Dimec), da Área Externa (Direx), de Política Monetária (Dipom) e de Política Econômica (Dipec).

3. ** Inclui as diretorias de Fiscalização (Difis), de Administração (Dirad) e de Normas (Dinor).

O perfil técnico e especializado dos nomeados é comprovado pela análise dos currículos. A formação desses profissionais, tanto os burocratas de carreira quanto os profissionais de fora, 
está estreitamente relacionada com sua área de atuação. Os burocratas e profissionais de fora são formados, majoritariamente, nas áreas afeitas às atividades financeira e bancária, como economia, administração e contabilidade. Como mostra a tabela abaixo, $85 \%$ dos diretores e presidentes são formados nestas áreas, mas com predominância de economistas.

TABELA3 - FORMAÇÃO DOS PROFISSIONAIS DE FORAE BUROCRATAS

\begin{tabular}{|l|c|c|}
\hline \multicolumn{1}{|c|}{$\begin{array}{c}\text { ÁREAS DE } \\
\text { FORMAÇÃO }\end{array}$} & $\begin{array}{c}\text { QUANTI- } \\
\text { DADE }\end{array}$ & $\begin{array}{c}\text { PERCEN- } \\
\text { TUAL }\end{array}$ \\
\hline Economista & 38 & $58 \%$ \\
Administrador & 11 & $17 \%$ \\
Contador & 4 & $6 \%$ \\
Engenheiro & 4 & $6 \%$ \\
Economista e & 1 & $2 \%$ \\
Contador* & & \\
Administrador e & 1 & $2 \%$ \\
Contador* & 1 & $2 \%$ \\
Advogado & 3 & $5 \%$ \\
Outros & 2 & $3 \%$ \\
Não consta & 65 & $100 \%$ \\
TOTAL & & \\
\hline
\end{tabular}

\section{FONTE: a autora.}

NOTA: * Dupla formação devido à realização de dois cursos de graduação ou de graduação e pós-graduação em áreas diferentes.

A proporção de profissionais com nível de pósgraduação é elevada. Pouco mais da metade deles (54\% do total) concluiu cursos de pós-graduação - Master Business Administration (MBA) e stricto sensu. Entretanto, há grande disparidade entre burocratas e profissionais de fora, pois são poucos os funcionários que realizaram cursos de pós-graduação em comparação com os de fora (33\% dos burocratas e $68 \%$ dos profissionais de fora).

A instituição em que foram obtidos os títulos mostra um alto grau de internacionalização dos estudos, uma vez que a maioria dos cursos de doutorado foi realizada em universidades no exterior, sendo boa parte delas instituições acadêmicas de grande prestígio acadêmico internacional, conforme tabela a seguir.
TABELA 4 - ÁREAS E INSTITUIÇÕES DOS DOUTORADOS

\begin{tabular}{|c|c|}
\hline UNIVERSIDADE & $\begin{array}{l}\text { NÚMERO DE } \\
\text { DOUTORES }\end{array}$ \\
\hline \multicolumn{2}{|c|}{ Universidades no exterior } \\
\hline $\begin{array}{l}\text { Massachussetts Institute of } \\
\text { Technology }\end{array}$ & 4 \\
\hline Harvard University & 3 \\
\hline $\begin{array}{l}\text { University of California } \\
\text { (Berkeley) }\end{array}$ & 3 \\
\hline Princeton University & 2 \\
\hline Stanford University & 1 \\
\hline $\begin{array}{l}\text { The Johns Hopkins } \\
\text { University (Baltimore) }\end{array}$ & 1 \\
\hline $\begin{array}{l}\text { New School for Social } \\
\text { Research }\end{array}$ & 1 \\
\hline $\begin{array}{l}\text { Scuola Superiores Matte } \\
\text { (Milão) }\end{array}$ & 1 \\
\hline London School of Economics & 1 \\
\hline Subtotal & 17 \\
\hline \multicolumn{2}{|c|}{ Universidades no Brasil } \\
\hline Universidade de São Paulo & 5 \\
\hline Fundação Getúlio Vargas & 1 \\
\hline Subtotal & 6 \\
\hline TOTAL & 23 \\
\hline
\end{tabular}

FONTE: a autora.

NOTAS:

1. Todos os doutorados no exterior foram na área de Economia.

2. Dos doutorados no Brasil, três foram na área de Contabilidade, dois em Economia e um em Administração.

No caso dos burocratas, a competência técnica e a especialização estão estreitamente ligadas à carreira. Os burocratas são todos concursados e a maioria especializa-se, ao longo da carreira, em uma das divisões internas do Banco Central (câmbio e operações internacionais, normas de regulação do sistema financeiro, fisscalização, política monetária, controle interno, meio circulante e recursos humanos). Apesar de, em média, terem nível educacional menor do que os profissionais do mercado, se considerarmos que são poucos os funcionários que realizaram cursos de pós-graduação, eles obtêm a formação e a especialização necessárias dentro da própria instituição, uma vez que boa parte deles freqüentou cursos internos do Banco Central. 
Esse perfil de carreira dos burocratas corresponde às características tradicionais do sistema de mérito: acesso impessoal e mediante provas de conhecimento, trajetórias de carreira fechadas e regidas pela progressão nos cargos. Por meio do sistema meritocrático, o Banco Central conforma um corpo de funcionários diferenciado quanto a suas habilidades, com identidade profissional própria e estreitamente vinculada à instituição.

Há, entretanto, burocratas que destoam deste padrão geral, apresentando perfil de carreira mais parecido com o dos profissionais de fora: um perfil híbrido, com mais circulação entre instituições e com mais inserção na rede.

Os profissionais com perfil híbrido, sejam burocratas ou profissionais do mercado privado, caracterizam-se pela passagem por várias instituições, tanto públicas quanto privadas, anteriormente à ocupação do cargo de direção no Banco Central. Entre estas instituições estão bancos públicos e privados, instituições financeiras privadas, órgãos do governo (predominantemente na área econômica, como secretarias do Ministério da Fazenda ou empresas estatais) e instituições de ensino e pesquisa acadêmica.

Os burocratas híbridos estão entre os poucos burocratas que chegam à Presidência do Banco Central e às diretorias de política monetária e cambial, que são postos geralmente ocupados por profissionais de fora. Essa diferença na distribuição de burocratas e profissionais de fora entre os cargos é um reflexo das diferenças no perfil dos nomeados. Somente os profissionais com perfil híbrido, que mesclam competências técnicas e políticas, sejam eles profissionais de fora ou burocratas, ocupam a Presidência e as diretorias de política macroeconômica, ou seja, ocupam as posições de policymaker.

\section{TABELA 5 - DISTRIBUIÇÃO DOS BUROCRATAS}

\begin{tabular}{|c|c|c|}
\hline CARGO & HÍBRIDO & $\begin{array}{c}\text { NÃO- } \\
\text { HÍBRIDO }\end{array}$ \\
\hline Presidência & 4 & 0 \\
\hline $\begin{array}{l}\text { Diretorias de política } \\
\text { monetária e cambial }\end{array}$ & 4 & 0 \\
\hline $\begin{array}{l}\text { Diretorias de fiscalização, } \\
\text { normatização e administração }\end{array}$ & 7 & 11 \\
\hline
\end{tabular}

NOTAS: A respeito das Diretorias de Política Monetária e Cambial e das Diretorias de Fiscalização, Normatização e Administração, cf. Tabela 2, acima.
A diferença quanto ao tipo de cargo ocupado por burocratas e por profissionais de fora indica que chegar aos altos escalões não é decorrência natural da carreira burocrática, mas de habilidades pessoais e profissionais específicas. A força do vínculo institucional dos burocratas com a instituição pode ser ilustrada pela afirmação de um entrevistado - um burocrata com perfil híbrido e altamente inserido na rede social - sobre as vicissitudes da circulação do burocrata por várias instituições. Segundo ele, o funcionário que atua fora da burocracia permanece com o "DNA de servidor público". Em outras palavras, mesmo os burocratas que passaram uma parte de suas carreiras fora do Banco Central, trabalhando em instituições financeiras privadas ou realizando cursos de pós-graduação, mantêm intacta a vinculação com o ethos burocrático e com a instituição. Apesar disso, só a carreira e o "DNA" não levam o burocrata aos cargos de direção da política macroeconômica, aos cargos de policymaker. Para chegar a esses cargos, mesmo em uma instituição meritocrática e organizada em carreiras como o Banco Central, são necessárias outras habilidades ou características "não-burocráticas", como a habilidade de sacrificar a pureza burocrática em nome do apoio político (SCHNEIDER, 1994) e de desenvolver habilidades políticas e comunicativas.

Quais são, então, as habilidades exigidas de um policymaker do Banco Central, seja ele burocrata ou profissional de fora?

A ampliação dos espaços e das habilidades do burocrata típico é reflexo do fenômeno da politização da burocracia e da burocratização da política descrito por Aberbach, Putnam e Rockman (1981). De acordo com seu modelo de dirigente híbrido, como já vimos, os dirigentes do alto escalão combinam as funções e habilidades burocráticas e políticas. Os burocratas que se tornam policymkers, assumindo a Presidência do Banco Central ou as diretorias diretamente relacionadas com a gestão da política macroeconômica, foram capazes de desenvolver algumas habilidades pessoais específicas (como capacidade de articular as necessidades técnicas com as políticas) e de construir outras lealdades além da lealdade organizacional com o Banco Central, a que a maioria dos burocratas fica restrita.

Conforme um burocrata de carreira do Banco Central que concedeu entrevista, a separação ní- 
tida entre formuladores e implementadores de políticas - e a tentativa de atribuir tal papel aos políticos, e aquele, aos burocratas - é ultrapassada e inútil, pois esses papéis misturam-se, em especial nos altos escalões. O entrevistado referiu-se à sua participação na formulação de um plano econômico da década de 1990. Na visão dele, sua participação não encaixaria-se propriamente à figura do formulador, pois ele não estava entre os que haviam elaborado a proposta original do plano. Entretanto, sua posição também não era passiva como a de um simples implementador, pois o próprio processo de formulação do plano, bem como sua implementação, dependeram de informações cruciais prestadas por ele sobre o funcionamento das operações e da máquina burocrática e sobre o histórico de planos anteriores. Ou seja, sua participação foi mais ativa do que esse modelo "formulador versus implementador" poderia supor para um burocrata, mas sem que ele tivesse transformado-se em um formulador propriamente dito.

Além disso, existem habilidades intrinsecamente relacionadas com a especificidade da atuação do Banco Central em relação às demais políticas públicas. Como já vimos, o dirigente da autoridade monetária precisa equilibrar os interesses privados e o interesse público ao exercer seu poder de regulação sobre o mercado.

A habilidade de equilibrar esses interesses depende, nas palavras de vários entrevistados, de "conhecer o outro lado do balcão". O burocrata que passa pela experiência de trabalhar em instituições financeiras privadas conhece melhor os interesses do mercado, seu ponto de vista e sua lógica de ação, bem como as limitações do poder do Banco Central. No entanto, o profissional do mercado que atua como dirigente público passa a conhecer como o governo funciona e quais são os obstáculos institucionais e políticos à ação dos dirigentes. Aprende também as agruras de colocar o comprometimento com a responsabilidade do cargo acima dos objetivos pessoais.

A passagem pelo Banco Central dá instrumentos importantes para o profissional do mercado. Ele passa a conhecer as engrenagens do funcionamento do governo e aprende que a "vontade política" do dirigente público está restringida por inúmeros obstáculos institucionais e políticos. Nas palavras de um entrevistado, o dirigente "tem que aprender a engolir sapo", pois ele não pode "dei- xar o barco" diante de decisões difíceis ou de ameaças à sua reputação. Uma vez no cargo, o dirigente não pode guiar-se apenas pelos seus objetivos pessoais, mas deve estar à altura da responsabilidade pública do cargo.

Alguns entrevistados com carreiras predominantemente no setor privado referem-se a essa experiência em cargos públicos como parte do "serviço militar" que devem prestar ao país após terem atingido sucesso profissional e estabilidade financeira. Porém, seria ingênuo acreditar que a passagem pelo Banco Central é apenas um ato altruísta que coroa carreiras empresariais bemsucedidas.

A passagem pelo Banco Central pode alavancar carreiras no setor privado, não apenas pelo fato de dar visibilidade ao nomeado, que passa a ostentar o valioso título de ex-diretor do Banco Central. O profissional também adquire habilidades específicas, valorizadas no mercado. Após ocupar o núcleo de decisão sobre política macroeconômica do país, o "ex-BC" - como o ex-dirigente é identificado nos jornais diários e nas revistas semanais passa a conhecer os limites do poder da autoridade monetária, os pontos fracos da instituição e como as decisões são tomadas no governo. Esse tipo de conhecimento é muito importante no mercado financeiro, cujo funcionamento gravita, muitas vezes, em torno de expectativas sobre as decisões do governo, e é especialmente valioso para os profissionais que tornam-se consultores, vendendo conselhos a partir da avaliação das ações futuras das instituições governamentais.

A experiência fora do seu meio institucional "natural" também é importante para o burocrata típico. Esse burocrata tem a visão apenas da autoridade monetária, visão que pode mostrar-se limitada na hora de relacionar-se com o mercado. Já o burocrata híbrido, segundo um entrevistado, conhece o mercado financeiro "por dentro" e "entende sua lógica". Ele aprende a criticar o Banco Central, aprende a ver de forma mais clara os limites, os erros e exageros de sua atuação como autoridade monetária. O burocrata que circulou por instituições privadas compreende de forma mais acurada a visão do mercado sobre a atuação do Banco Central, aprende a antecipar as reações do mercado e torna-se mais capaz de calibrar suas próprias decisões, porque conhece "a mente típica de quem está do outro lado". A política monetária depende, em boa parte, de como o mercado 
avalia as decisões do Banco Central, ou seja, da habilidade do burocrata em comunicar de forma precisa suas decisões. Se os agentes econômicos avaliam corretamente os movimentos do Banco Central, conseguirão relacionar-se melhor com o banco, e a política tende a obter os resultados esperados.

Outra característica importante do burocrata híbrido é sua capacidade de "falar a mesma língua" que os diretores de fora. Esta expressão usada por um entrevistado significa a capacidade de os funcionários relacionarem-se de forma complementar e cooperativa com os diretores de fora, por terem cursado pós-graduação ou por terem experiência no mercado. Muitos entrevistados avaliaram a atitude dos burocratas perante os profissionais de fora que assumem diretorias no Banco Central como cooperativa, e isso faz parte do profissionalismo dos burocratas. Mas, além do profissionalismo, há habilidades específicas de comunicação que diferenciam os burocratas, e isso também é importante para os que não estão nos cargos de diretoria.

Falar a mesma língua significa a ampliação da capacidade de diálogo entre os profissionais de fora e os funcionários de carreira. Esses burocratas híbridos atuam, então, como "guias de cego", conforme definiu outro entrevistado. Os diretores de fora recorrem a estes funcionários mais experientes porque não teriam condições de aprender em poucos meses todos os meandros da atividade do Banco, o que requer um grande conhecimento da sua memória institucional. Conforme as palavras de outro entrevistado, são os burocratas híbridos que, por dominarem as engrenagens da máquina, "tocam o barco" nas diretorias ocupadas por profissionais de fora pouco familiarizados com esses mecanismos.

A aliança e a cooperação entre diretores de fora e burocratas são essenciais para a formulação e implementação de políticas. A elaboração de políticas públicas, na maioria das burocracias, é um processo de formação de coalizão, assistência mútua e negociação (SCHNEIDER, 1994), e os burocratas raramente ficam passivos ou à margem desse processo, mesmo quando não ocupam cargos de direção. Uma relação baseada no diálogo e na confiança mútua, fundamental para a negociação e a formação da coalizão, desenvolve-se mais facilmente quando os profissionais compartilham as mesmas visões de mundo ou o mesmo jargão profissional. Experiências profissionais e acadêmicas semelhantes, decorrentes da vivência nas mesmas instituições, promovem esta identidade de visões e de discursos que facilitam a aliança e a cooperação.

\section{CONSTRUÇÃO DA COMPETÊNCIA E DA CONFIANÇA POR MEIO DA REDE SOCIAL}

A partir dos relatos das entrevistas e da análise dos currículos dos nomeados, foram construídos dois critérios de nomeação dos presidentes e diretores do Banco Central: competência profissional e confiança pessoal. O critério de competência é composto por atributos pessoais e atributos profissionais. O critério de confiança, por sua vez, é composto de atributos pessoais e atributos relativos à rede social.

O critério de competência profissional inclui atributos pessoais como inteligência e seriedade, além de atributos profissionais como formação acadêmica sólida, especialidade nas áreas financeira ou bancária (ou nas divisões internas do Banco Central, no caso dos burocratas), experiência profissional e competência técnica.

O critério de confiança pessoal inclui atributos pessoais como integridade moral e ética, espírito público e atributos relativos à rede social, como amizade, indicação por pessoa próxima e/ ou respeitável, afinidade de pensamento, experiência reconhecida no meio financeiro e credibilidade entre os profissionais de sua área de atuação.

A diferença analítica fundamental não está na oposição entre competência e confiança. Nas entrevistas, ao falar sobre a importância da competência como critério de nomeação, os entrevistados não realçavam o componente profissional da competência, como a formação acadêmica ou a experiência profissional. Esse componente era considerado "óbvio" ou "natural", dadas as exigências do cargo. A análise dos currículos, de fato, confirma que os nomeados têm formação compatível com as exigências técnicas do cargo ou função. $\mathrm{O}$ que os entrevistados ressaltavam era o componente pessoal da competência, ou seja, inteligência e seriedade. Mais do que um esforço de auto-elogio ou um exercício de diplomacia, esta ênfase nos atributos pessoais relativos à competência profissional indica a importância das relações pessoais na definição e na aferição da competência profissional. 
Esta diferenciação analítica entre atributos pessoais e profissionais da competência profissional permite analisar a peculiaridade dos atributos pessoais exigidos do profissional que ocupará a direção do Banco Central, conforme aparece no discurso dos entrevistados. Essa ênfase nos atributos pessoais da competência, como inteligência e seriedade, está relacionada com a peculiaridade da atividade exercida pelo Banco Central. De acordo com um entrevistado, o Banco Central "é o lugar mais delicado da República", devido ao tipo de informações a que os diretores têm acesso. São informações que "valem ouro" e exigem do diretor não apenas firmeza de caráter na sua utilização, mas também capacidade de manter sigilo e de saber omitir informações ao público, quando necessário. De fato, o Banco Central não apenas lida com informações sensíveis, em que o sigilo e o compromisso com o bem público são fundamentais, mas exerce um tipo peculiar de autoridade política, que exige habilidades específicas para a intermediação entre interesses públicos e privados, como já foi analisado anteriormente.

A importância da distinção entre critérios de competência e de confiança não está em reforçar a oposição entre técnica e política, como se houvesse uma correspondência estanque e absoluta entre critérios técnicos e de competência, de um lado, e entre critérios políticos e de confiança, de outro. Os critérios de confiança e de competência não opõem-se. Eles são distintos, mas complementares. Os critérios complementam-se na medida em que os atributos pessoais exigidos dos nomeados incluem tanto critérios de confiança, como relação de amizade, quanto de competência, como inteligência e seriedade. O componente político da nomeação não reduz-se às relações pessoais de confiança, mas inclui atributos profissionais como respeito profissional, afinidade de pensamento, experiência e credibilidade profissionais. A importância da distinção entre critérios de competência e de confiança é possibilitar a identificação do papel das relações pessoais e da rede social nas nomeações, principalmente nas nomeações regidas fortemente pelo critério técnico, mas sem recair na oposição entre clientelismo e insulamento, entre política e técnica; ou seja, sem (des)qualificar o conteúdo político das nomeações como elemento espúrio.

Como estas habilidades ou atributos pessoais são, então, avaliados pelo nomeador? Como são controlados ou monitorados?

Os atributos pessoais e profissionais dos nomeados são conhecidos pelo nomeador por intermédio do relacionamento próximo entre eles (seja pessoal ou profissional) ou pelo reconhecimento de terceiros, que indicam algum profissional conhecido, afiançando seus atributos pessoais e/ou profissionais. Nenhum ex-Presidente relatou ter escolhido seus diretores com base em uma análise fria, impessoal e objetiva de currículos. Pelo contrário, eles baseiam-se em informações que pessoas do seu círculo pessoal ou profissional e de sua confiança podem fornecer sobre o caráter e o desempenho dos indicados ou em sua própria experiência de trabalho ou relacionamento pessoal com o indicado.

$\mathrm{Na}$ falta de procedimentos impessoais e institucionalizados de avaliação de mérito, os presidentes recorrem às relações de confiança, às relações pessoais. Ou seja, a importância das relações familiares e de amizade na nomeação não indica que sejam nomeados amigos ou parentes, como em uma relação clientelista, mas que as relações pessoais são a forma de aferição da competência e dos atributos de caráter. Esse relacionamento próximo pode ser decorrente de experiência profissional conjunta, que não apenas cria ou estreita laços pessoais, mas permite ao nomeador avaliar a competência do nomeado in loco, analisando sua atuação enquanto profissional, além de reconhecer suas habilidades pessoais, como a postura de comando e a integridade ética.

A relação de confiança, tão importante segundo os relatos dos entrevistados, não reflete relações personalistas, no sentido clientelista ou patrimonialista do termo. Ela significa uma forma de controle sobre a performance futura dos nomeados, ou seja, uma forma de redução dos riscos intrínsecos à delegação de poder entre nomeador e nomeado, e esta confiança não é unilateral, ela deve ser mútua. O nomeador, por um lado, deve confiar no nomeado, como forma de garantir-se quanto à conduta ética e profissional de seus subordinados. Por outro, o nomeado também deve confiar no nomeador para aceitar o convite. De acordo com um entrevistado, para avaliar se aceitaria "o desafio de dirigir o Banco Central", o indicado também faz considerações sobre os atributos pessoais e profissionais dos 
demais componentes da diretoria e da equipe econômica pois, ao aceitar o convite, o nomeado não está apenas aproveitando a possibilidade de alavancar sua carreira ou de prestar seu "serviço militar" ao país, mas também está arriscando-se a comprometer-se com decisões de grande envergadura e de alto risco político e profissional. Como a história recente revela, as escolhas e decisões políticas exigidas pelo exercício da autoridade monetária podem destroçar reputações e afundar carreiras promissoras.

Essas relações pessoais e profissionais de confiança estabelecem-se na medida em que o profissional circula entre as diversas instituições públicas, privadas e da área acadêmica. Esta circulação aporta ao profissional, por uma lado, uma variedade de experiências profissionais - em instituições públicas e privadas - e de conhecimentos (práticos e/ou acadêmicos), aumentando, portanto, as habilidades e competências do profissional, como já foi ressaltado na seção anterior. Por outro, a circulação também aumenta a possibilidade de o indicado ter seu desempenho profissional e suas habilidades pessoais reconhecidas e aferidas por outros profissionais. Este processo reforça-se automaticamente, pois a multiplicação de vínculos pessoais e profissionais decorrente da circulação aumenta a probabilidade de o profissional receber convites para trabalhar em outras instituições, bem como a quantidade de pessoas que podem atestar seu desempenho e suas habilidades.

Essa multiplicação dos vínculos pode ser ilustrada graficamente por rede de relacionamentos. Os nomeados têm, na sua grande maioria, mais de um vínculo dentro da rede, com profissionais de várias instituições e não apenas com quem os tenha nomeado.

A rede social foi construída a partir das informações colhidas nos currículos e nas entrevistas. As flechas que ligam os nomes representam os vínculos entre ex-presidentes da república, exministros da Fazenda, ex-diretores e ex-presidentes do Banco Central. Como não foi possível entrevistar muitos burocratas, foi adicionado o ator "burocrata" (localizado, na Rede, acima/à esquerda) para representar a ligação dos nomeados com burocratas do $\mathrm{BC}$ que não tiveram seus nomes revelados.

Pode-se perceber como alguns nomes têm muitas flechas a eles relacionadas, indicando que são pessoas altamente inseridas na rede, como no caso de ex-presidentes do BC (Gustavo Loyola, Pedro Malan, Fernão Bacher, Ibraim Eris) e de formuladores de planos econômicos (Pérsio Arida, André Lara Resende). As entrevistas indicaram que eles não apenas ocuparam postos de destaque no $\mathrm{BC}$ como mantêm-se na rede após o término de sua passagem pelo governo, pois permanecem como referências de outros profissionais cuja nomeação esteja sendo cogitada.

Os ex-presidentes do BC são como pólos que concentram várias ligações com outros profissionais. Ibraim Eris, por exemplo, que foi presidente do BC entre 1990 e 1991 e era profissional híbrido por ter carreira no setor privado e na academia (era professor na Faculdade de Economia da USP), está "conectado" com a Ministra da Fazenda na época, Zélia Cardoso de Melo, sua colega na USP, que o indicou para o então Presidente Fernando Collor, bem como aos seus diretores Eliseu Martins (colega de Eris na USP), Luis Eduardo Assis (ex-aluno e colaborador de Eris) e Antônio Sochaczewski (indicado a Eris por Antonio Kandir, assessor da Ministra Zélia) - localizado, na Rede, acima/à direita).

Outros profissionais, ao contrário, têm poucas ligações na rede, geralmente, apenas com a pessoa que os indicou ou recomendou, como é o caso de Luis Fernando Figueiredo, diretor de política monetária entre 1999 e 2003. Profissional não-híbrido, com carreira apenas no setor privado (mais especificamente, no setor bancário), Figueiredo foi recomendado pelo seu ex-patrão no banco BBC, Fernão Bracher, ao então Presidente do BC, Armínio Fraga, que precisava montar uma equipe nova após a saída de Gustavo Franco (que foi Presidente do BC entre 1997 e 1999) em decorrência da crise cambial de 1999. Bracher foi Presidente do BC entre 1985 e 1987 e é um profissional freqüentemente citado nas entrevistas entre aqueles consultados sobre nomeações até hoje (Figueiredo consta na Rede como LFigueiredo, no centro, à esquerda). 


\section{FIGURA 1 - REDE SOCIAL}

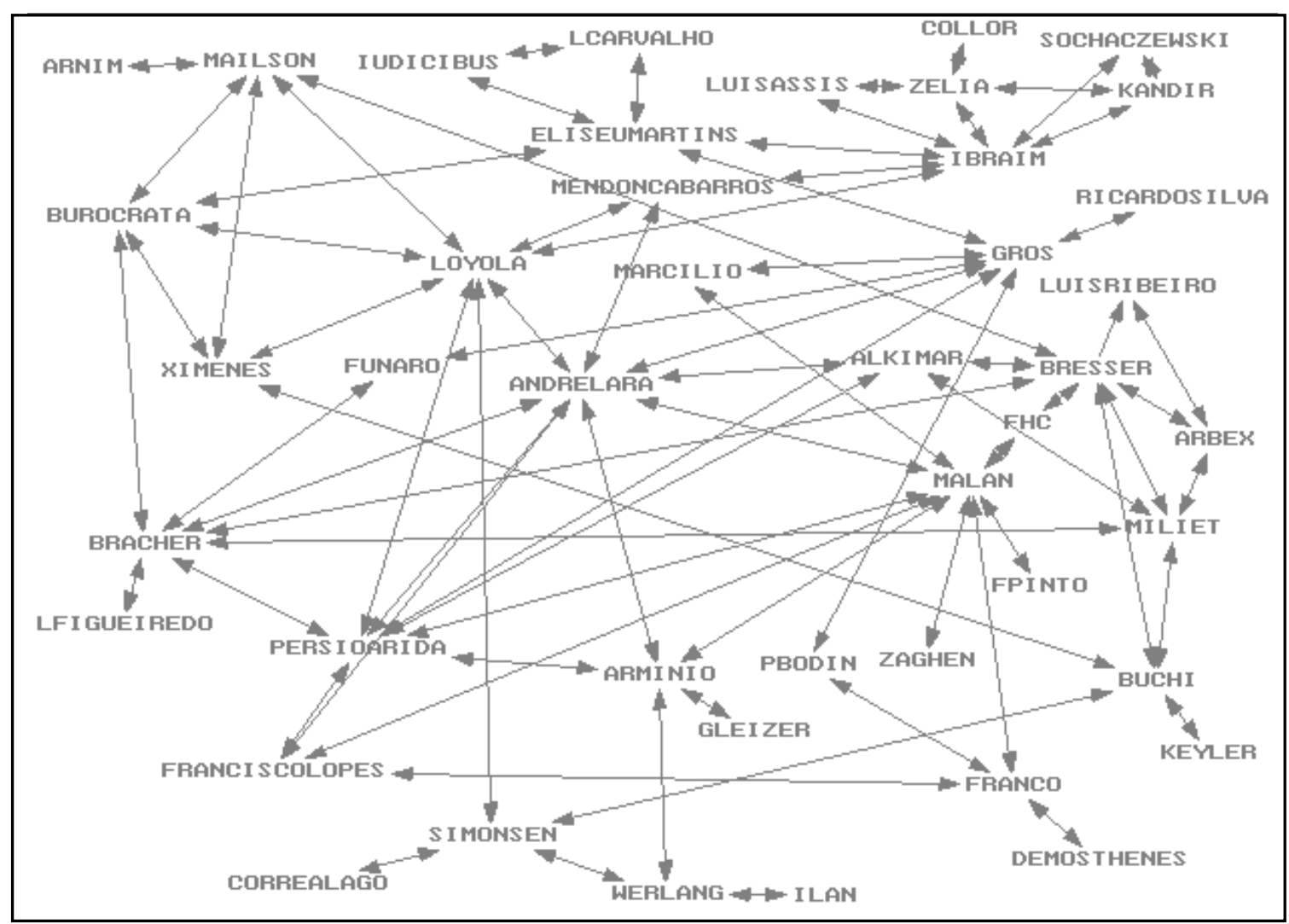

FONTE: a autora.

O laço é mais forte para os burocratas, pois eles provêm de uma mesma instituição, da qual suas carreiras são mais dependentes e que conforma um ethos profissional mais definido e fortemente identificado com a instituição. Os profissionais de fora, ao contrário, não vivem em uma só empresa, mas transitam por várias instituições privadas, em especial da área financeira. Tanto burocratas quanto profissionais de fora têm conexão com um terceiro espaço institucional, o das instituições de ensino superior e pesquisa, nacionais e internacionais. Essa conexão com instituições de ensino, por sua vez, é, como já vimos, mais freqüente e mais internacionalizada entre os profissionais de fora.

O que interessa-nos é a compreensão do processo de nomeação e não uma análise sociológica dos grupos profissionais. Assim, essas características são vistas como formas de aferir, avaliar e garantir os atributos pessoais e profissionais dos nomeados no processo de preenchimento dos cargos. Para os objetivos deste trabalho, a longa convivência de dois profissionais na mes- ma instituição não mede a força de sua identidade profissional ou o seu comprometimento com a instituição, mas a capacidade de avaliação recíproca sobre suas habilidades e competências e a capacidade de atestá-la perante terceiros para promover indicações ou influenciar nomeações.

De acordo com discussões anteriores, são as carreiras híbridas e não as carreiras fechadas que levam aos cargos de direção da política econômica. Os policymakers caracterizam-se por carreiras híbridas e pela conciliação de habilidades técnicas e políticas. Para alcançar os cargos relacionados à política monetária, ou seja, para a nomeação aos cargos de Presidente do Banco Central e às diretorias da área monetária e cambial, os laços fortes são importantes, mas não decisivos. Eles são importantes porque o profissional precisa ter especialidade profissional e reconhecimento entre seus pares. Mas o que é decisivo é o desenvolvimento de laços fracos fora de sua instituição de origem, para adquirir outras habilidades, como já foi analisado, e para dispor de fontes de reconhecimento diversificadas. Como, então, a rede opera? 
Como não é possível, nos limites deste artigo, descrever a trajetória de todos os profissionais entrevistados para evidenciar o funcionamento da rede, descreveremos a trajetória de carreira de um burocrata híbrido, que permite exemplificar vários mecanismos de avaliação recíproca e de indicação de nomeações. Este burocrata entrou no Banco Central por meio de concurso público aos 25 anos de idade, logo após o término do curso superior de Economia. Sua primeira experiência fora do Banco Central ocorreu três anos após o ingresso, para cursar pós-graduação em economia na Escola de Pós-Graduação em Economia da Fundação Getúlio Vargas do Rio de Janeiro (EPGE-FGV-RJ). Nosso burocrata passou quatro anos no Rio de Janeiro, licenciado de suas atividades no Banco Central, e retornou a Brasília com os títulos de mestre e doutor na bagagem. A escolha da EPGE deu-se em função do contato do burocrata com professores dessa escola, que haviam sido diretores do Banco Central, e pela especialização da escola e de seus professores na área de estudo desejado: política monetária. Destaque-se a preeminência, no relato do entrevistado, do contato prévio com os professores da escola para definir sua opção acadêmica.

Sua segunda experiência fora da burocracia, cinco anos após o retorno do Rio de Janeiro (RJ), foi para trabalhar em uma corretora de valores. O convite foi feito por um profissional de fora que ocupou uma diretoria do Banco Central e que trabalhara junto de nosso burocrata. Novamente, os laços pessoais desenvolvidos no próprio Banco Central com profissionais do mercado que ocupam diretorias no Banco foram essenciais para propiciar novas oportunidades profissionais ao funcionário. Ele permaneceu dois anos na corretora, licenciado do Banco Central.

Essa passagem pelo mercado propiciou não apenas a aquisição de experiência sobre "o outro lado do balcão", mas também sua primeira nomeação para uma diretoria. Algum tempo depois de seu retorno ao Banco Central, o burocrata foi nomeado por um ex-colega da corretora de valores que assumiu a Presidência do Banco. A experiência fora do Banco Central e os laços estabelecidos com profissionais do mercado foram determinantes, portanto, de sua ascensão a uma diretoria. Este profissional do mercado que assumiu a Presidência e nomeou o burocrata à diretoria relatou que a experiência prévia de trabalho com esse burocrata no mercado privado foi critério determinante da nomeação. Ele ficara impressionado com o desempenho do burocrata na corretora e, além disso, não conhecia ninguém da burocracia do Banco Central quando foi nomeado Presidente. Este burocrata não apenas ocupou uma posição destacada na diretoria, como tornou-se o principal mediador entre o Presidente e a burocracia do Banco Central.

O vínculo profissional entre representantes de instituições diferentes e com experiências variadas promove nomeações diretas, como indica o exemplo acima, e também indiretas, por indicação de nomes. Muitos entrevistados relataram ter solicitado informações sobre a experiência profissional e a reputação de indicados a pessoas conhecidas. Quanto maior a inserção deste profissional na rede, ou seja, quanto mais contatos ele detém, maior a chance de conseguir informações confiáveis sobre a reputação do indicado, e maior a chance de não decepcionar-se com seu desempenho futuro. Profissionais do mercado híbridos têm mais inserção na rede, por isso, contam com conhecimento mais amplo sobre potenciais indicados, e têm mais condições de encontrar nomes que considerem adequados. Seus laços fracos são mais numerosos, pois eles trabalharam diretamente ou tiveram experiência profissional próxima com um número mais alto de pessoas, em um número maior de instituições.

Adicionalmente, os presidentes que estão compondo sua equipe costumam reforçar sua avaliação sobre algum nome, checando com outros profissionais as credenciais ou atributos pessoais e profissionais do indicado. Ao procurar indicação ou referência sobre pessoa de outro meio profissional, o Presidente não precisa ter uma grande circulação em outros meios, mas precisa conhecer pessoas a quem possa pedir indicação de profissionais de outras instituições. Por meio dos laços fracos, o nomeador amplia seu leque de opções e tem maiores condições de se certificar sobre os atributos dos escolhidos.

As pessoas consultadas sobre as credenciais de outros profissionais têm duas qualidades: são próximas do nomeador o suficiente para prestar informação sobre a reputação de seus pares sob sigilo e também detêm suficiente conhecimento sobre o indicado e o espaço institucional em que ele atua para prestar informações fidedignas. As 
pessoas consultadas precisam, portanto, ter circulado por várias instituições e ter uma alta inserção na rede. Entre as pessoas consultadas, foram citados os membros da equipe econômica, colegas de profissão que tinham mais convivência com $\mathrm{o}$ indicado e profissionais com atuação de destaque, como presidentes de bancos privados e profissionais que participam do debate público sobre política econômica, além de indivíduos com os quais o nomeador tenha afinidades intelectuais.

Essas pessoas que fornecem conselhos são ouvidas não apenas porque são da confiança do nomeador, mas porque são pessoas experientes na área, já tendo ocupado o cargo de Presidente do Banco Central ou Ministro da Fazenda, e porque compartilham a linha teórica do nomeador. São pessoas que têm trânsito em várias instituições, sejam públicas, privadas ou acadêmicas. Trata-se de profissionais com uma extensa rede de contatos e que tornam-se grandes influenciadores de equipes do Banco Central. Alguns destes "notáveis" chegam a tomar a iniciativa de indicar nomes a presidentes do Banco Central recém-empossados e que estão à caça de talentos para sua equipe, em uma tentativa de influenciar a política econômica por intermédio da nomeação de alguém que compartilhe seus interesses ou preferências políticas.

As instituições de ensino e pesquisa exercem papel muito importante nesse processo de aferição de competência e de reconhecimento. A passagem por essas instituições é muito mais do que uma forma de adquirir a competência técnica e a especialização que, como vimos, constituem requisitos fundamentais dos nomeados. Esta passagem aporta aos profissionais o reconhecimento às suas posições teóricas e políticas, constrói reputações e define afinidades intelectuais.

Analisando os fatores de legitimação dos economistas como uma nova elite dirigente, Maria Rita Loureiro destaca a importância do reconhecimento internacional dos profissionais da academia para a aprovação política e acadêmica no Brasil. A “[...] internacionalização da ciência econômica inaugura novas formas de acesso ao poder e de legitimação da elite dirigente. A notoriedade acadêmica é garantida por fortes vínculos com o circuito científico internacional, e a visibilidade que ela propicia na imprensa, no meio empresarial e político do país é grande" (LOUREIRO, 1997, p. 79).
Um exemplo desta forma de legitimação de idéias econômicas foi o percurso de Pérsio Arida e André Lara Resende para obter prestígio internacional à tese inercialista da inflação. Em 1984, eles expuseram e debateram suas idéias com pesquisadores e funcionários de agências internacionais no centro de pesquisa Woodrow Wilson (onde Pérsio Arida estava trabalhando na época), no Fundo Monetário Internacinal (FMI) e no Federal Reserve (LOUREIRO, 1997). Após esta exposição internacional, o tema ganhou destaque no Brasil graças ao endosso de Mario Henrique Simonsen às idéias de Arida e Lara Resende. A respeitabilidade de Simonsen, um dos principais economistas brasileiros da época, colocou Arida e Lara Resende na imprensa e no debate público nacional. Esta visibilidade e reconhecimento foram importantes para sua participação na elaboração do Plano Cruzado, em 1986, e do Plano Real, em 1993.

Os profissionais com origem na academia geralmente tornam-se conhecidos do mercado ao prestar serviços de consultoria ou ao serem alçados a posições de direção no governo por colegas ou professores. Os relatos dos entrevistados e os perfis de carreira revelam a atração que a atividade de consultoria exerce sobre alunos e professores de Economia, Administração e Contabilidade. Em alguns centros de ensino, as empresas de consultoria estão dentro das próprias universidades. Esta atividade paralela de consultoria abre um caminho para a construção de carreiras ambivalentes, que conciliam pesquisa e docência com atividades de prestação de serviços a empresas privadas ou ao governo.

Estes professores ou alunos não aportam ao mercado apenas conhecimento especializado, mas também prestígio acadêmico. Loureiro (1997) evidencia três critérios que determinam o prestígio dos consultores: 1) a relevância dos postos que ocuparam no governo, o conhecimento da máquina administrativa e as relações com atuais funcionários que esta passagem promoveu; 2) a visibilidade na imprensa, com a publicação de artigos em jornais e revistas não-acadêmicas; 3) o prestígio da universidade de origem (LOUREIRO, 1997).

A transformação de acadêmicos respeitados na sua área, mas desconhecidos do grande público e sem capital político, em personalidades públicas notáveis e com legitimidade para propor 
planos econômicos depende desses mecanismos de legitimação. O primeiro passo é o pertencimento ou a passagem pelos principais centros acadêmicos na área monetária, como PUC-Rio, EPGE-FGV-RJ e USP. Estas três universidades constituem referência na área de política monetária e cambial no Brasil, e isso refletese nos currículos dos diretores do Banco Central. A maioria dos diretores de fora com curso de pós-graduação cursaram estas universidades.

Existe uma forte correlação entre a presença de colegas de universidade na diretoria de presidentes que desenvolveram carreiras ambivalentes, no mercado e na academia. Isso não ocorre apenas devido à afinidade intelectual e teórica necessária em qualquer equipe, mas por causa das conexões e relações de confiança entre ex-colegas, à semelhança das relações entre profissionais com experiência profissional conjunta. Isto não significa, é claro, que os presidentes só indiquem diretores com formação na mesma faculdade que a sua nem que a passagem pela mesma instituição garanta, automaticamente, esta afinidade (recentemente, dois renomados professores de Economia da mesma instituição de ensino, e que ocuparam diretorias no Banco Central no mesmo período, trocaram farpas publicamente por causa de discordâncias teóricas).

A afinidade intelectual entre membros da equipe não revela apenas a importância dos relacionamentos promovidos no ambiente institucional das faculdades e que são acionados no processo de nomeação. Ela também garante uma certa coesão da equipe, uma afinidade de visões e de propósitos, que pode facilitar a tarefa do Presidente de assegurar-se sobre o desempenho futuro do nomeado. A afinidade intelectual garante a eficiência do trabalho em equipe e o controle sobre os resultados da atuação dos nomeados.

\section{CONSIDERAÇÕES FINAIS}

Dois temas importantes permearam a discussão deste trabalho, apesar de não terem sido tratados explicitamente: as relações entre Estado e sociedade e a responsabilização governamental ou, na expressão mais freqüentemente utilizada na literatura, accountability. A análise das nomeações para os cargos de confiança por meio das redes sociais permite avançar as reflexões sobre estas questões. $\mathrm{O}$ estudo das carreiras dos nomeados a partir das redes sociais permite identificar mais claramente o padrão de relação entre Estado e sociedade. Este padrão deve ser levado em consideração nas análises sobre a accountability governamental, na medida em que pode constituir um empecilho à institucionalização de mecanismos de responsabilização no processo de escolha dos ocupantes de cargos públicos de direção.

O profissional híbrido que circula na rede experimenta a atividade de regulador, ao exercer a autoridade monetária como dirigente do Banco Central, e a de regulado, ao trabalhar no mercado financeiro. Ele personifica a inter-relação entre carreiras e conhecimentos específicos dos setores público e privado.

Existe um interesse recíproco do setor público e do setor privado em relação aos conhecimentos específicos produzidos em cada área. Este interesse tende a ser pequeno em relação ao conhecimento produzido em áreas com pouca interface com o mercado como, por exemplo, a diplomacia, cujo conhecimento tem pouca utilidade para o setor privado, mas é muito grande nos campos em que o Estado atua como regulador do mercado, como na área financeira. Esta diferença reflete-se na forma de contratação dos funcionários destas áreas: o Estado, por um lado, dedica recursos especificamente para o treinamento e a formação dos futuros diplomatas, em vez de contratá-los "prontos" no mercado de trabalho, mas, por outro, contrata operadores do mercado financeiro para dirigir o Banco Central, de modo a beneficiar-se da expertise promovida pelas carreiras privadas na área financeira.

Este aproveitamento de competências construídas no mercado privado é tradicional nas diretorias de política macroeconômica, como já vimos. Na última década, entretanto, ele tem ocorrido de forma intensa na diretoria da área externa. Com a transformação das formas de financiamento do Estado na década de 1990, caracterizada pela substituição dos empréstimos bancários pela negociação no mercado de títulos e pela atração de investimentos estrangeiros, o perfil de diretores da área externa alterou-se profundamente. Funcionários do Banco Central treinados em negociações de dívida externa foram substituídos por profissionais de fora especializados em mercados financeiros internacionais e investimento estrangeiro e com experiência e circulação em instituições internacionais de administração de fundos de investimento (OLIVIERI, 2002). 
Quanto maior o interesse do setor privado no conhecimento produzido dentro do Estado menor a diferenciação entre elite pública e elite privada (SCHNEIDER, 1995). Esta proximidade caracteriza o profissional híbrido. Ela também é um dos fatores que materializa a autonomia inserida, ou, na expressão original, a embedded autonomy, ou seja, uma forma de relacionamento entre a sociedade e uma instituição estatal em que os contatos entre a sociedade e a instituição não caracterizam-se pelo insulamento em relação à sociedade, mas ocorrem por meio de uma certa permeabilidade (EVANS, 1995). No caso do Banco Central brasileiro, esta permeabilidade estabelece-se pela rede social de relacionamentos pessoais e profissionais.

Segundo Ben Schneider (1995), a caracterização da inserção autônoma, ou embeddedness, da instituição a partir da trajetória de carreira dos profissionais não é fácil, no caso do Brasil, porque estas trajetórias são muito diversificadas, promovendo lealdades múltiplas e sobrepostas (ibidem). Os servidores podem ligar-se a seus próprios órgãos ou a outros grupos políticos, e essa rotatividade desarticula as ligações pessoais que caracterizam os anéis burocráticos (ibidem). Para Schneider, a circulação pode reduzir a força desses vínculos, reduzindo a embeddedness.

Entretanto, se pensarmos em termos de uma rede de relações, e não apenas em carreiras individuais e rotatividade de cargos, podemos perceber de forma mais acurada o padrão da embeddedness. A circulação entre as diversas instituições públicas, privadas e da área acadêmica aporta aos profissionais uma variedade de experiências profissionais e de conhecimentos, aumentando suas habilidades e competências. Este processo reforça-se automaticamente, pois a multiplicação de vínculos pessoais e profissionais decorrente da circulação aumenta a probabilidade de o profissional receber convites para trabalhar em outras instituições, bem como a quantidade de pessoas que podem atestar seu desempenho. A rede pode ter o efeito contrário ao da rotatividade, como esta foi concebida por Schneider (1995), porque mantém estas ligações ao longo do tempo, mesmo quando seus membros não estão ocupando cargos de direção no governo. A fraqueza dos laços entre os profissionais não extingue a rede nem a condena a desaparecer; a rede tem a propriedade de emergir ou submergir, conforme seus membros estejam, respectivamente, ocupando algum cargo no governo ou não. A rede não desfaz-se com a circulação; pelo contrário, ela alimenta-se justamente da circulação.

Além de caracterizar a embeddedness, a rede também contribui para o controle do Presidente da República sobre a burocracia ao criar mecanismos de aferição de competências dos nomeados e ao promover habilidades de comunicação e negociação, necessárias aos policymakers.

A nomeação para os cargos de direção é um dos principais instrumentos de controle do Presidente da República sobre a burocracia ${ }^{3}$ (WOOD $\&$ WATERMAN, 1991). A escolha dos ocupantes dos cargos de livre provimento é uma das formas pelas quais os políticos podem garantir que a burocracia trabalhe de acordo com a agenda do governo, ou seja, é instrumento para direcionar os esforços da burocracia para a consecução dos objetivos dos políticos eleitos.

Analisando a responsabilidade e a accountability governamentais a partir da relação entre ministros e seu staff estável na Austrália, Delmer Dunn aponta como a comunicação é essencial para conciliar a perspectiva do político com a do burocrata. Habilidades de comunicação e negociação são elementos importantes na definição de uma relação complementar entre políticos e burocratas (DUNN, 1999). Uma boa comunicação permite a definição e a informação claras das decisões do Ministro à burocracia e a delimitação das responsabilidades dos burocratas perante seus superiores. A falta de comunicação gera uma relação de desconfiança entre políticos e burocratas, que pode emperrar o trabalho e, no limite, impedir a responsabilização e a accountability.

As condições de responsabilização entre políticos e burocratas podem ser promovidas pelas capacidades de negociação e conciliação de interesses desenvolvidas na rede. Essas capacidade não aumentam apenas a eficiência do desempenho do governo, como já vimos, mas também a

3 As outras formas de controle da burocracia, segundo Wood e Waterman (1991), são: controle orçamentário, reorganização da estrutura administrativa, monitoramento e legislação. 
accountability horizontal. Além disso, a rede social também contribui para a accountability horizontal ao suprir a ausência de instrumentos formais definidores de critérios de escolha dos nomeados, garantindo uma certa segurança ao Presidente sobre o desempenho futuro dos nomeados. Contudo, o papel da rede como forma de aferição de competências pode reduzir a responsabilização entre governantes e governados (accountability vertical). A rede tem, portanto, efeitos ambivalentes sobre a accountability. A rede restringe a possibilidade de escrutínio público sobre a definição e aferição dos critérios de nomeação, pois eles são "negociados" entre nomeador e nomeado; ainda que esta negociação não seja puramente privada, pois a rede amplia as instâncias institucionais intervenientes, ela também não é propriamente pública, ou seja, realizada sob as vistas do público.

A possibilidade de escrutínio público sobre ao atos do governo, como a escolha para os cargos de confiança, determina, em boa parte, as condições de responsabilização entre governantes e governados. Neste sentido, a forma como a rede funciona contribui para a redução da transparência da escolha dos dirigentes públicos, pois um mecanismo fundamental da partilha do poder no Brasil - a distribuição dos cargos do governo fica à margem do debate e do escrutínio públi$\cos$. A afirmação de que os critérios de nomeação são puramente técnicos é ingenuidade, ignorância ou, o que é pior, uma forma de tentar retirar a decisão sobre a distribuição dos cargos do âmbito do debate público.

O mecanismo clássico de escrutínio público das nomeações de dirigentes públicos é a confirmação da indicação do poder Executivo pelo poder Legislativo após argüição pública. Entre 1988 e $1999^{4}$, o Senado aprovou todas as indicações de diretores e presidentes do Banco Central apresentadas pelo Presidente da República (ANASTASIA, 2000). Este alto nível de aprovação (100\% de aprovação) pode ser considerado forte indicador da indiferença da participação do Senado no processo de provimento. Ou seja, o

\footnotetext{
4 A Constituição Federal de 1988 estabeleceu a obrigatoriedade da argüição pública e da aprovação das indicações à diretoria do Banco Central pelo Senado Fede-
} ral (BRASIL, 2002, art. 52, III, alínea d).
Senado não estaria cumprindo seu papel de instância de controle sobre o governo ou, pelo menos, sobre as nomeações políticas.

Como ainda não há estudos específicos sobre o papel do poder Legislativo no processo de provimento de cargos no Brasil, não se pode afirmar que o papel do Senado seja desprezível, ainda que constate-se a inexistência de veto formal do Senado aos nomes apresentados pelo Presidente da República. Nos Estados Unidos, a influência do Senado no processo de provimento aos cargos da administração federal não expressa-se na votação contra os nomes apresentados pelo poder Executivo, mas na elevada consideração das preferências do Senado pelo governo na própria escolha dos nomes a serem indicados (MACKENZIE \& SHOGAN, 1996). Não pode-se, portanto, desprezar a hipótese da relevância do papel do Senado na aprovação das indicações, pois ela pode manifestar-se em negociações anteriores à votação da indicação.

Nas entrevistas, os ex-diretores referiram-se aos debates sobre política macroeconômica promovidos durante a sessão de argüição como pobres e irrelevantes, o que a leitura das atas das sessões confirma. Entretanto, eles ressaltaram a importância da sabatina como mecanismo de garantia do controle democrático e da transparência das ações do governo. A exposição pública dos nomes dos indicados promoveria, na opinião dos entrevistados, possibilidade maior de controle democrático sobre as nomeações para o órgão de direção da política econômica. Pessoas sem qualificação ou cuja atividade profissional implicasse conflitos de interesse seriam mais facilmente impedidas de assumir postos tão importantes pelo fato de o Senado controlar as indicações em processo público e transparente. São hipóteses que aguardam verificação.

Este trabalho ressaltou alguns aspectos das nomeações que podem promover a responsabilização, e apontou fatores potencialmente redutores da accountability. Estudos nesta área precisam ser aprofundados. Mas o trabalho contribuiu para a delimitação e compreensão de elementos fundamentais das análises das instituições que promovem, ou não, a accountability do governo, como as relações entre políticos e burocratas, a distribuição de atribuições e responsabilidades entre estes dois atores e os efeitos das nomeações nesta relação. 
Cecília Olivieri (ceciliaolivieri@gvmail.br) é Mestre em Ciência Política pela Universidade de São Paulo (USP), Professora da Faculdade Santa Marcelina (FASM) e doutoranda em Administração Pública e Governo na Escola de Administração de São Paulo da Fundação Getúlio Vargas (EAESP/FGV).

\section{REFERÊNCIAS BIBLIOGRÁFICAS}

ABERBACH, J.; PUTNAM, R. \& ROCKMAN, B. 1981. Bureaucrats and Politicians in Western Democracy. Cambridge, Mass. : Harvard University.

ABRANCHES, S. H. 1988. Presidencialismo de coalizão : o dilema institucional brasileiro. $D a$ dos, Rio de Janeiro, v. 31, n. 1, p. 5-34.

ANASTASIA, F. 2000. A responsabilização da administração pública por controle parlamentar : Argentina, Bolívia, Brasil e Chile. Artigo apresentado no XXIV Encontro Anual da Associação Nacional de Pesquisa e Pós-Graduação em Ciências Sociais, realizado de 23 a 27 de outubro, em Caxambu (Minas Gerais). Digit.

COHN, G. 1993. Introdução. In : WEBER, M. Parlamento e governo na Alemanha reordenada: crítica política do funcionamento e da natureza dos partidos. Petrópolis : Vozes.

DUNN, D. D. 1999. Mixing Elected and NonElected Officials in Democratic Policy Ma- king : Fundamentals of Accountability and Responsibility. In : PRZEWORSKI, A.; STOKES, S. \& MANIN, B. (eds.). Democracy, Accountability, and Representation. Cambridge : Cambridge University.

EVANS, P. 1995. Embedded Autonomy. Princeton : Princeton University.

GEDDES, B. 1990. Building "State" Autonomy in Brazil, 1930-1964. Comparative Politics, v. 22, n. 2, p. 217-235, Jan.

GRANOVETTER, M. 1973. The Strength of Weak Ties. The American Journal of Sociology, v. 78 , n. 6 , p. 1360-1380, May.

1983. The Strength of Weak Ties: A Network Theory Revisited. Sociological Theory, v. 1, p. 201-233.

LOUREIRO, M. R. 1997. Os economistas no governo : gestão econômica e democracia. Rio de Janeiro : Fundação Getúlio Vargas.

LOUREIRO, M. R. \& ABRUCIO, F. 1998. Burocracia e política na nova ordem democráti- ca brasileira : o provimento de cargos no alto escalão do governo federal (governos Sarney, Collor, Itamar Franco e FHC). Relatório de pesquisa. São Paulo : Fundação Getúlio Vargas.

1999. Política e burocracia no presidencialismo brasileiro : o papel do Ministério da Fazenda no primeiro governo Fernando Henrique Cardoso. Revista Brasileira de Ciências Sociais, São Paulo, v. 14, n. 41, out.

MACKENZIE, G. C. \& SHOGAN, R. 1996. Obstacle Course: The Report of the Twentieth Century Fund Task Force on the Presidential Appointment Process. New York : The Twentieth Century Fund.

MARQUES, E. C. 1999. Redes sociais e instituições na constituição do Estado e da sua permeabilidade. Revista Brasileira de Ciências Sociais, São Paulo, v. 14, n. 41, out.

MARTINS, L. 1985. Estado capitalista e burocracia no Brasil pós 64. Rio de Janeiro : Paz e Terra.

NUNES, E. 1999. A gramática política do Brasil : clientelismo e insulamento burocrático. $2^{\mathrm{a}}$ ed. Rio de Janeiro : J. Zahar.

O'DONNELL, G. 1998. Accountability horizontal e as novas poliarquias. Lua Nova, n. 44.

OLIVIERI, C. 2002. A política de nomeação do alto escalão do Banco Central do Brasil (1985-2000). São Paulo. Dissertação (Mestrado em Ciência Política). Universidade de São Paulo.

SCHNEIDER, B. R. 1994. Burocracia pública e política industrial no Brasil. São Paulo : Sumaré.

1995. A conexão da carreira : uma análise comparativa de preferências e insulamento burocrático. Revista do Serviço Público, Brasília, v. 119, n. 1, jan.-abr.

SOLA, L. 1995. Estado, regime fiscal e ordem monetária : qual Estado? In : Lições da década de 80. São Paulo : USP. 
SOLA, L.; GARMAN, C. \& MARQUES, M. 1998. Central Banking, Democratic Governance and Political Authority : the Case of Brazil in a Comparative Perspective. Revista de Economia Política, São Paulo, v. 18, n. 2, p. 106-131, abr.-jun. Disponível em : http:/ /www.rep.org.br/pdf/70-8.pdf. Acesso em : 3.maio.2007.

SOUZA, M. C. C. 1976. Estado e partidos politicos no Brasil (1930-1964). São Paulo : AlfaÔmega.
WEBER, M. 1993. Parlamento e governo na Alemanha reordenada: crítica política do funcionamento e da natureza dos partidos. Petrópolis : Vozes.

WOOD, B. D. \& WATERMAN, R. W. 1991. The Dynamics of Political Control of the Bureaucracy. The American Political Science Review, Washington, D. C., v. 85, n. 3, p. 801828 , Sept.

\section{OUTRAS FONTES}

BRASIL. 2002. Constituição da República Federativa do Brasil : promulgada em 5 de outubro de 1988. 29a ed. São Paulo : Saraiva.
BRASIL. Ministério do Planejamento. Secretaria de Recursos Humanos. 2005. Boletim estatistico de pessoal. Brasília, v. 106, fev. Disponível em : Boletim estatístico de pessoal. Acesso em : 3.maio.2007. 
POLITICS, BUREAUCRACY AND SOCIAL NETWORKS: THE CASE OF NOMINEES FOR HIGH LEVEL POSITIONS WITHIN THE BRAZILIAN CENTRAL BANK (BANCO CENTRAL DO BRASIL)

Cecília Olivieri

The study of nominees to high level positions within the Brazilian Central Bank (Banco Central do Brasil) through social network analysis enables us to understand fundamental aspects of the Brazilian political and administrative system. Choice of public administrators affects the governability and governing of the country. The exchange of positions for parliamentary support can work to guarantee government stability, but it may also reduce the president's control over bureaucracy and the management of public policies. Social network analysis makes it possible to determine what criteria have been used in the choice of public administrators, revealing new patterns of State-society interface and paving the way for the study of accountability in the relationship between public administratores and bureaucracy, and between government and society.

KEYWORDS: nominations; bureaucracy; social networks; Banco Central do Brasil; accountability. 
POLITIQUE, BUREAUCRATIE ET RÉSEAUX SOCIAUX: LES NOMINATIONS AUX POSTES MAJEURS DE LA BANQUE CENTRALE DU BRÉSIL

\section{Cecilia Olivieri}

L'étude des nominations aux postes majeurs de la direction de la Banque Centrale du Brésil au moyen d'analyses de réseaux sociaux nous permet de compreendre les aspects fondamentaux du système politico-administratif brésilien. Le choix des dirigeants du secteur public touche la gouvernabilité et la gouvernance du pays. L'échange de postes et d'appui parlementaire au gouvernement assure sa stabilité. Par contre, cela peut diminuer le contrôle du président de la République sur la bureaucratie et la direction des politiques publiques. L'analyse de réseaux sociaux aide à connaitre l'organisation des critères de choix des dirigeants du système public, révèle de nouveaux modèles d'interface entre l'État et la société et illlumine l'étude de l'accountability entre dirigeants publics et la bureaucracie et entre le gouvernement et la société.

MOTS-CLÉS: nommination; bureaucracie; réseaux sociaux; Banque centrale; l'accountability. 